DOI https://doi.org/10.30525/978-9934-26-073-5-1-8

\title{
ТРАНСПОЗИЦІЇ СПОСОБОВИХ І ЧАСОВИХ ФОРМ ДІССЛОВА В УКРАЇНСЬКІЙ МОВІ
}

\author{
Нестеренко Т. А. \\ кандидат філологічних наук, \\ дочент кафедри української мови \\ Центральноукраїнського державного педагогічного університету \\ імені Володимира Винниченка \\ м. Кропивницький, Украӥна
}

Граматичний лад української мови характеризується існуванням абстрактних за своєю природою понять, що відбивають позамовну діяльність і типологічні особливості всієї мовної структури. Результатом ïx поглибленого пізнання $\epsilon$ вироблення найзагальніших інтегральних одиниць, позначуваних терміном граматичні категорії. Граматичні категорії $є$ ядерними компонентами мовної організації, які, грунтуючись на корелятивній взаємозалежності двох або кількох граматичних значень, виражених певною системою співвідносних граматичних форм, реалізуються в системі мови, пронизують усю іï структуру та взаємодіють між собою.

У сучасних дослідженнях поняття граматичної категорії опрацьоване переважно на матеріалі морфологічних категорій, які сконцентровано у двох центральних частинах мови - іменнику та дієслові. У вивченні часової дієслівної транспозиції існує певна традиція, вироблена пошуками вітчизняних (В. М. Барчук, І. Р. Вихованець, К. Г. Городенська, А. П. Загнітко) [2; 3; 4] та зарубіжних науковців (О. В. Бондарко, Л. Теньєр, Ш. Баллі) [6; 5; 1]. При цьому внутрішній механізм транспозиції зазвичай залишається не з'ясованим або розглядається побіжно, не завжди мотивується характер супровідних конотацій, деякі типи функціювання способових або часових форм, що кваліфікують як переносні вживання, насправді не є такими. Звідси випливає необхідність дослідити функційні транспозиції способових і часових форм дієслова, особливо в комунікативно-прагматичному аспекті.

Категорії часу й способу з позицій функційної граматики української мови кваліфікують як суто морфологічні дієслівні категорії словозмінного типу [3]. Категорія способу дієслова є граматичним центром значно ширшої функційно-семантичної категорії (ФСК) модальності, а категорія часу - ядром ФСК темпоральності. ФСК модальності та спосіб 
дієслова і, відповідно, ФСК темпоральності й час дієслова перебувають в ієрархічних відношеннях, тому ототожнювати їх не варто.

Підстав для виокремлення дійсного способу в складі категорії способу немає. По-перше, приписуваний йому семантичний зміст реалізує категорію часу, якій надається статус самостійної граматичної категорії дієслова саме на цій семантичній основі. По-друге, у дійсному способі відсутні спеціальні формальні засоби вираження (як синтетичні, так i аналітичні).

У двочленній морфологічній категорії способу грамеми наказового та умовного способів $є$ нерівнорядними за своєю суттю, оскільки різняться структурою, семантикою, проте їхній зміст відзначається однорідністю, бо передає значення ірреальності: протиставлення нереальних (гіпотетичних / бажаних) дій $є$ онтологічною суттю морфологічної категорії дієслівного способу. Обидві грамеми морфологічної категорії способу знаходять своє вираження в ряді словоформ.

Транспозиція здійснюється внаслідок перенесення граматичної форми 3 природного для неї, граматично зумовленого середовища в інше, яке є властивим іншій формі, що знаходиться з першою в певних парадигматичних відношеннях; граматичне перенесення здійснюється на грунті семної спільності граматичного значення транспонованої форми i форми, ужитої у своїй первинній функції. Взаємної транспозиції зазнають модальні й темпоральні значення. Це спричиняє перенесення форм часу у сферу способу й навпаки.

Унаслідок модальної транспозиції дієслова відбувається накладання способової семантики транспонованої форми на функційну семантику комунікативного контексту; виникає семна двоплановість, яка стає причиною перебудови в семантичній структурі граматичного значення способу (перерозподіл сем і зміна ієрархічного співвідношення між ними).

У сучасній українській мові транспозиція в площині модальності дієслова охоплює всі дієслівні способи. Найпродуктивнішим у цьому плані $\epsilon$ наказовий спосіб - він транспонується у сферу значень умовного способу та в часову площину й має досить розгалужену систему метафоричних уживань.

Особливості морфологічних форм наказового способу зумовлюють можливість їх заміни іншими дієслівними формами за збереження граматичного значення наказовості. Форми наказового способу в окремих синтаксичних умовах можуть переходити у площину гіпотетичної ірреальності або навіть набувати значень реальності. Відзначається зв'язок наказового способу з умовним та 3 категорією часу. Модальні 
відтінки притаманні наказовим формам, співвіднесеним 3 формами минулого часу.

Умовний спосіб характеризується найвужчим спектром транспозиційних уживань, хоча може функціонувати із значеннями імператива й індикатива. Умовний спосіб, що трансформується у відповідних контекстуальних умовах у наказовий спосіб, $є$ контамінацією обох способів і тому поєднує форму одного, а зміст іншого, тобто він утворюється за допомоги форм умовного способу, але має значення наказового. Взаємодія умовного способу з іншими виявляється в здатності умовного способу виступати функційним еквівалентом реальної дії або переходити в зону імперативності, 3 одного боку, 3 іншого, транспонуватися в площину інших часових та способових форм. Уживання умовного способу замість наказового, за рахунок взаємодії яких передається спонукання, $є$ фактично єдиною вторинною функцією умовного способу.

У ході темпоральної транспозиції дієслова відбувається накладання часової семантики транспонованої форми на часову семантику комунікативного контексту; виникає семна двоплановість, яка $\epsilon$ причиною появи контрасту на вербальному рівні (форма - словесний контекст). Транспозиція часових форм в українській мові охоплює всі три темпоральні дистанції: минулий, теперішній, майбутній.

Минулий час уживається зі значеннями теперішнього й майбутнього, причому в метафоризації беруть участь форми доконаного й недоконаного видів. Транспозиція форм минулого часу в зону презенса реалізується насамперед у плані абстрактного теперішнього й розширеного теперішнього. Уживання минулого часу в функції актуального теперішнього більш обмежене не тільки контекстом, а й семантикою дієслів : минулий недоконаний демонструє транспозицію небагатьох лексем, зокрема хотіти. Транспозиція минулого в площину майбутнього також обмежується низкою чинників: лінгвістичними (ознака «доконаність», лексична семантика дієслів, вербальний, інтонаційний контекст), паралінгвістичними (ситуативний контекст). Найпоказовішими в цьому плані $є$ минулий у значенні небажаного майбутнього, минулий iз значенням близького майбутнього, минулий із значенням допустового майбутнього.

Теперішній час транспонується в площину минулого й майбутнього. Головною ознакою цих типів темпоральної метафори $є$ унаочнення й актуалізація подій минулого. Більш уживаними у функції теперішнього історичного й теперішнього емоційної актуалізації виступають лексеми на позначення найважливіших дій фізичної та інтелектуальної сфери 
людини йти, їхати, сидіти, говорити, бачити, дивитись, запитувати, відповідати, думати тощо. Віднесеність дії до майбутнього може також передаватися сусідством 3 формами майбутнього недоконаного, випливати із загального значення контексту.

Майбутній час транспонується у сфери значень минулого й теперішнього, характеризуючись тісною взаємодією 3 категорією модальності. Найширший спектр метафоричних уживань мають форми майбутнього доконаного. Майбутній доконаний реалізується в різних типах передавання минулої дії: повторювана відносно тривала дія, повторювана несподівана дія, короткочасна інтенсивна дія 3 визначеною кратністю. Майбутній недоконаний реалізує значення майбутнього емоційної актуалізації. У значенні теперішнього широко функціонують форми майбутнього часу дієслова бути (як самостійно, так і в складеному дієслівному присудку).

Отже, явище транспозиції як результат переносного вживання способових і часових форм підпорядковане загальним закономірностям функціонування мови.

\section{Література:}

1. Балли Ш. Общая лингвистика и вопросы французского язика. М. : Изд. иностр. лит., 1955. 384 с.

2. Барчук В. Граматична темпоральність: Інтервал. Час. Таксис: Монографія. Івано-Франківськ: Сімик, 2011. 416 с.

3. Вихованець І. Р., Городенська К. Г. Теоретична морфологія української мови. К. : Пульсари, 2004. 398 с.

4. Загнітко А. П. Теоретична граматика української мови. Морфологія. Донецьк : ДонДУ, 1996. 435 с.

5. Теньер Л. Основы структурного синтаксиса : монография; пер. с франц. И. М. Богуславский и др.; вст. ст., общ. ред. и коммент. В. Г. Гак. М. : Прогресс, 1988. С. 534-535.

6. Теория функциональной грамматики. Темпоральность. Модальность / отв. ред. А. В. Бондарко. Л. : Наука, 1990. 264 с. 